\title{
RELATION BETWEEN DIVERSITY OF PHYTOPLANKTON AND ENVIRONMENTAL FACTORS IN WATERS AROUND NANRI ISLAND
}

\author{
Ye, Y. Y. ${ }^{1}-$ LuO, Y $.^{1,2^{*}}-$ WANG, Y. ${ }^{1}-$ LIN, M. ${ }^{1}-$ XIANG, P. ${ }^{1 *}-$ AshraF, M. A. ${ }^{3,4}$ \\ ${ }^{I}$ Third Institute of Oceanography, SOA, Xiamen 361000, China \\ ${ }^{2}$ College of Environmental Science and Engineering, Ocean University of China, Qingdao \\ 266100, China \\ ${ }^{3}$ Faculty of Science \& Natural Resources, University Malaysia Sabah 88400 Kota Kinabalu, \\ Sabah, Malaysia \\ ${ }^{4}$ International Water, Air \& Soil Conservation Society, Kuala Lumpur, Malaysia \\ *Corresponding author \\ e-mail: xiangpeng@tio.org.cn,luoyang@tio.org.cn \\ (Received 24 $4^{\text {th }}$ Oct 2016; accepted 20 $0^{\text {th }}$ Dec 2016)
}

\begin{abstract}
Based on the investigation in waters around Nanri Island in spring and autumn of 2011, we analyzed spatial and temporal changes in species, abundance and diversity index of phytoplankton, and explored the relation between phytoplankton community structure and environment. The result showed that 106 species of phytoplankton, in 48 genera were identified, wherein diatom was the dominant species in abundance. Abundance in spring was significantly higher than that in autumn, ecological groups feature eurythermal and warm water species. Investigation showed that the heterogeneity of the marine environment of was high, and phytoplankton species diversity was low. Salinity and nutrients, as two major factors that influenced temporal and spatial variation of phytoplankton distribution abundance, were significantly correlated with phytoplankton abundance in spring. Compared to islands survey data during 1990-1991, dominant species were mainly few species, which succeed from domination of both dinoflagellate and diatom to domination of diatom.
\end{abstract}

Keywords: field survey; temporal and spatial distribution; community structure; influence of human activities; correlation

\section{Introduction}

Phytoplankton belongs to a concept of ecology (Fott et al., 1980). In the marine ecosystem, phytoplankton is primary producer, with its photosynthesis productivity about 95\% of all marine productivity (Reynolds, 1984). As the basic link in marine food web structure, it is the main food source for marine animals, affecting material circulation and energy flow of the entire food chain (Qi and Wang, 2003). Its rise and fall directly or indirectly affects productivity of the entire marine ecosystem (Gao, 2001). Changes in phytoplankton community structure and diversity can sensitively reflect impact of environmental changes on ecosystems, and its succession characteristics can record impact of natural variations and human activities on coastal ecosystems (Zhang, 2009; Liu, 2013; Wong and Tam, 1995; Committee of environmental experts, Ecological Society of Japan, 1987). Currently, extensive researches have been carried out in many countries on association of phytoplankton community structure in marine ecosystem and 
environmental factors. Cheng (1997), Jin (1982), Yang (1995), Xie et al. (2007), Lin and Yang (2007) found in analysis of phytoplankton community structure in Taiwan Strait that eurythermy species was the dominant phytoplankton in the region, followed by warm water species and temperate species. On the basis of integration of phytoplankton species diversity study on Taiwan Strait by cross-Taiwan Strait scholars, Lin et al. (2007) summarized that small phytoplankton in the Taiwan Strait totaled 620 species (Cheng, 1997; Jin, 1982; Yang, 1995; Li et al., 2015; Xie et al., 2007; Lin and Yang, 2007). By long-term observations of European North Sea, Patsch and Radach (1997) found that eutrophication was not only reflected by the change in the structure and concentration of nutrients, but also changed primary productivity and phytoplankton community structure (Patsch and Radach, 1997). Borkman and Smayda (2003) studied the United States Narragansett and found that water eutrophication led to nutritional structure of higher ratio of nitrogen and phosphorus, phytoplankton community structure was subjected to obvious succession. Since phytoplankton community structure and diversity changes can sensitively reflect impact of environmental change on ecosystems, its succession characteristics can record impact of natural variations and human activities on coastal ecosystems. Therefore, the study of phytoplankton community structure is of extremely important theoretical and practical value for understanding of the impact of environmental change on marine ecological system.

Nanri Island connects to Xinghua Bay, the largest bay in Fujian, in the north, adjoins Meizhou Bay in the south, facing the Taiwan Strait. Greatly affected by river systems such as Minzhe coastal current, continental runoff, South China Sea warm current, it shows complex river system characteristics (Zheng, 2014). Especially in the spring when Minzhe coastal current and South China Sea warm current join in sea waters near Nanri Island, forming high value area of nutrients and organic carbon (Liu et al., 2000; Hong, 1997), so where phytoplankton blooms and fishing people gather during spring flood period (Fujian Marine Research Institute, 1998). However, investigation on phytoplankton in waters around Nanri Island was only involved in comprehensive survey of island resources in 1990 (Du, 1996; Fujian Editorial Committee for Comprehensive Investigation of Sea Island Resources, 1994), with age-old data. Study of how changes in environmental factors affect phytoplankton diversity was rarely reported. Based on phytoplankton findings on west sea area of Nanri Island in spring and autumn of 2011, seasonal variation characteristics were analyzed by combining synchronized chemical data. In addition, we analyzed phytoplankton species composition, groups feature, abundance distribution in investigated area under influence of mixed changes of Minzhe coastal current, South China Sea warm current and the continental runoff in the two periods. Preliminary study was carried out on relation between environmental factors and phytoplankton community. Subsequently, by comparison to 1990-1991 survey data of the island, preliminary analysis was conducted on influence of marine environment changes in the investigated area over the past two decades on phytoplankton in the hope of accumulating base data for ecosystems study of the sea area and providing a scientific basis for comprehensive evaluation of impact of human activity on the marine environment.

\section{Materials and methods}

\section{Station setting and sample analysis}

12 stations were set up in waters around Nanri Island, in two quarters of 2011 spring (May) and autumn (October) to collect phytoplankton (Figure 1), with 24 phytoplankton samples collected. By referring to "National Standard GB / T 
12373.6-2007", $500 \mathrm{~mL}$ water sample was collected respectively from surface $(0.5 \mathrm{~m}$ from surface) and the bottom ( $1 \mathrm{~m}$ from the seabed). For some stations with water depth less than $5 \mathrm{~m}$ in a season, only surface water sample was collected. Samples were fixed with $5 \%$ neutral formalin to be precipitated for at least $24 \mathrm{~h}$. Then, carefully absorb supernatant with small siphon, repeat so, and finally concentrate to a certain volume by depending on the sample concentration. Extract separate sample, identify and count with phytoplankton counting plate under Olympus $\mathrm{BH}-2$ optical microscope, and calculate cell abundance (cells $\bullet$ L-1) according to the type.

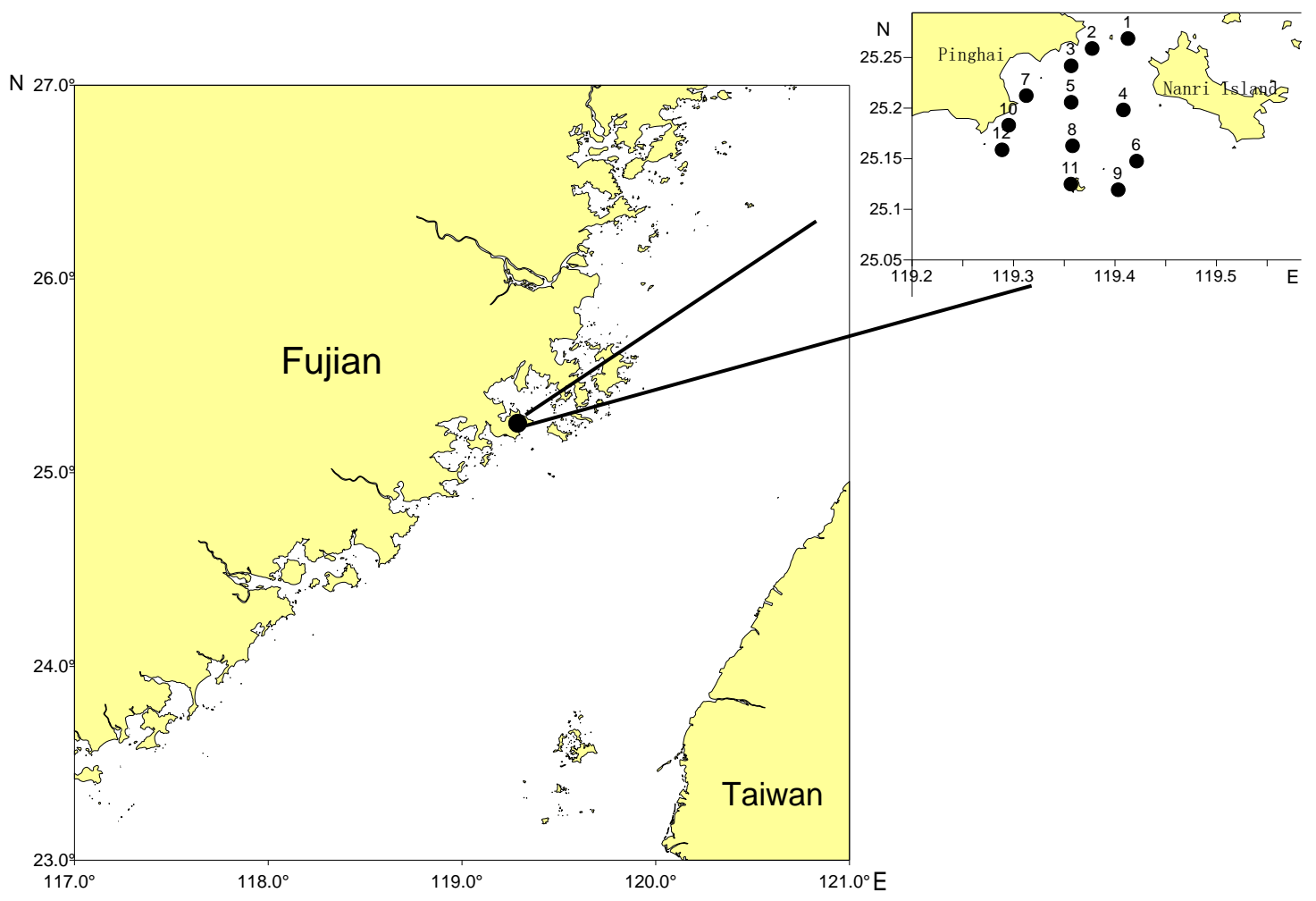

Figure 1. Diagram of stations for collection of phytoplankton in waters around Nanri Island

\section{Data analysis}

Phytoplankton diversity calculation applies Shannon-Wiener index formula:

Diversity index $H^{\prime}=\Sigma(n i / N) \log _{2}(n i / N)$, wherein, $n i$ is individual sum of $\mathrm{i}$-th species, $N$ is individual sum of all species;

Uniformity calculation applies Pielou uniformity formula: $J=H^{\prime} / \log _{2}(\mathrm{~S})$, wherein, $H^{\prime}$ is diversity index, $S$ is species number of phytoplankton (the total species number);

Dominance $Y=\left(n_{i} / N\right) \quad f_{i}, \quad n i$ is individual sum of $\mathrm{i}$-th species, $N$ is individual sum of all species, $f_{i}$ is frequency of the species in each sample.

\section{Data sources of environmental parameters and statistical test method}

Perform site determination of salinity, $\mathrm{pH}$ and other parameters; in accordance with sampling requirements of "Marine Monitoring Specification", collect dissolved oxygen (DO) and chemical oxygen demand (COD) samples to be brought to the laboratory and immediately measured; collect nutrition brine samples with plastic buckets, perform 
$0.45 \mu \mathrm{m}$ membrane filtration, add a few drops of chloroform and save at $-20{ }^{\circ} \mathrm{C}$, to be used for nutrient analysis and determination; determine nutrient with nutrient automatic analyzer (Skalar San plus), and determine with zinc cadmium reduction for $\mathrm{NO}_{3}$, diazo azo method for $\mathrm{NO}_{2}$, sodium hypobromite oxidation style for $\mathrm{NH}_{4}$, ascorbic acid reduction phosphorus molybdenum blue method for $\mathrm{PO}_{4}$, with alkaline permanganate titration for chemical oxygen demand and spectrophotometer for dissolved oxygen.

\section{Results and discussion}

\section{Species composition}

The results showed 96 species in 46 genera were identified (benthic species only include species floating in the water due to storms agitation), mainly including Diatom, Pyrrophyta, Chrypsophyta and Cyanophyta. Diatom, as the main phytoplankton, was decisive to phytoplankton species composition and number variation. As the main component of dominant species of phytoplankton, it featured Nitzschia, Coscinodiscus and Chaetoceros as the dominant groups, with 14, 12 and 10 species, respectively. Pleurosigma and Rhizosolenia were detected to be of many species; Ceratium and Alexandrum were rich in species.

Based on statistics according to occurrence frequency and cell density and size, the main species included Chaetoceros curvisetus, Paralia sulcata, Skeletonema costatum, Leptocylindrus danicus, Rhizosolenia stylilformis, Chaetoceros debilis, Lauderia borealis, Thalassiosira rotula and Eucampia zoodiacus. Among them, Skeletonema costatum was the dominant species of the two seasons, while Chaetoceros curvisetus and Paralia sulcata were respectively first dominant species in spring and autumn.

\section{Ecological groups}

The 106 species of phytoplankton in waters around Nanri Island can be divided into following three groups according to their distribution characteristics and ecological properties:

(1) Eurythermal species, which is with wide range of adaptation to temperature and can be subdivided into three species according to their different ranges of adaptation to salinity: (a) Eurythermal eurysalinity species: cosmopolitan distribution species with a wide scope of optimum temperature and salinity, such as Skeletonema costatum, Ditylum brightwellii, Pseudo-nitzchia pungens, Thalassionema frauenfeldii, Thalassionema nitzschioides, Ceratium furca, etc., which is quite common in study area with dominance in number; (b) Eurythermal low-salinity species: Chaetoceros curvisetus, Chaetoceros debilis, Cylindrotheca closterium, Eucampia zoodiacus, Leptocylindrus danicus, Paralia sulcata, Noctiluca scintilence; (c) Eurythermal high-salinity species: such as Thalassiosira rotula.

(2) Warm water species, a species suitable for distribution in high temperature seasons and waters, mainly including Lauderia borealis, Rhizosolenia stylilformis, Chaetoceros affinis, Chaetoceros compressus, Chaetoceros lorenzianus, Coscinodiscus jonensianus, Pseudo-nitzchia delicatissima, etc. The species is with many varieties, individual species cells are with high abundance, indicating South China Sea warm water with high temperature and salinity.

(3) Temperate species, which is with less species, such as Chaetoceros castracanei, Chaetoceros lauderi, Chaetoceros radians, Coscinodiscus oculatus, etc. 


\section{Seasonal changes in species number and different ecological species}

Survey results in 2011 spring and autumn showed that number of species (68) in the investigated area in spring was higher than that in autumn (53), of which spring eurythermal species accounted for $61.76 \%$ of the total and rose to $66.04 \%$ in autumn, while warm water species decreased from $16.18 \%$ in spring to $13.21 \%$ in autumn, temperate species shared a basically equal percentage in the total number of species between spring and autumn.

\section{Temporal and spatial distribution of phytoplankton abundance}

Spring (May) came with propagation of phytoplankton, during which, average abundance was $20.97 \times 10^{3}$ cells / $\mathrm{dm}^{3}$, surface average is $15.25 \times 10^{3}$ cells $/ \mathrm{dm}^{3}$, the bottom was $26.68 \times 10^{3}$ cells / $\mathrm{dm}^{3}$. In spring, water temperature rose $\left(18.72{ }^{\circ} \mathrm{C}\right)$, and driven by southwest monsoon, the influence of high temperature and high salinity water of South China Sea warm current gradually increased. In addition, regeneration, accumulation of nutrients during the winter and rich nutrients brought by continental runoff led to phytoplankton blooms. Seen from the plane distribution, coastal phytoplankton cell of the water was with large abundance, cell abundance values reach $20 \times 10^{3}$ cells $/ \mathrm{dm}^{3}$ or more. This was mainly because under influence of low temperature low salinity $\left(<15^{\circ} \mathrm{C},<30\right)$ of Minzhe coastal current, temperature species such as Chaetoceros curvisetus, Leptocylindrus danicus and Skeletonema costatum aggregated along the coast. Offshore phytoplankton was with lower abundance, $10 \times$ $10^{3}$ cells $/ \mathrm{dm}^{3}$ or less. The overall distribution of the spring phytoplankton abundance presents a decreasing trend from coastal sea (Fig. 2).

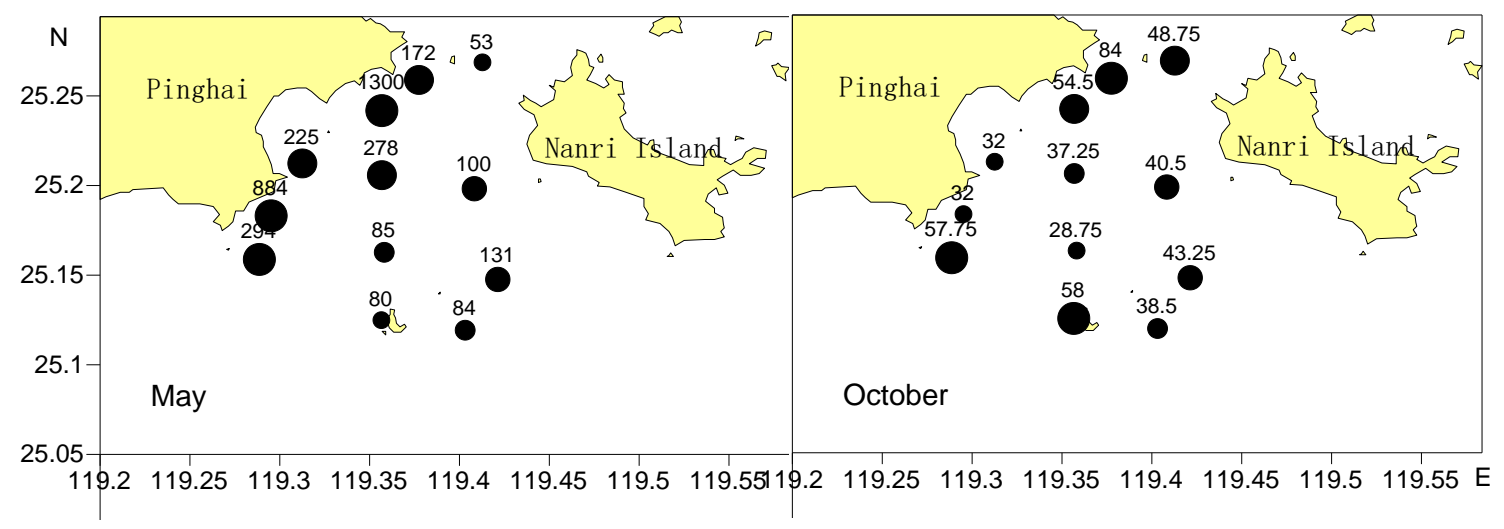

Figure 2. Horizontal distribution of phytoplankton abundance in spring and autumn (unit: $\times$ $10^{3}$ cells $/ \mathrm{dm}^{3}$ )

In autumn (October), average phytoplankton abundance was $4.63 \times 10^{3}$ cells $/ \mathrm{dm}^{3}$, surface average value was $4.09 \times 10^{3}$ cells $/ \mathrm{dm}^{3}$, the bottom was $5.17 \times 10^{3}$ cells $/ \mathrm{dm}^{3}$. With the enhancement of Minzhe coastal current, South China Sea warm current began to weaken, the region's water temperature, salinity generally decreased, phytoplankton growth rate gradually slowed with rapid decline in abundance. Phytoplankton cell abundance of the investigated area showed trend of higher value in north and south poles and lower value in the middle. The main high value area was distributed in northern coast of the investigation area, with cell abundance value over $5 \times 10^{3}$ cells / $\mathrm{dm}^{3}$ or more. This was because under influence of tongue of low temperature and low 
salinity water of Minzhe coastal current, a large number of eurythermal species such as Paralia sulcata, Skeletonema costatum gathered into high abundance in these stations. Sub high-value areas were mainly concentrated in offshore stations S11-S12, which may be because eurythermal species such as Paralia sulcata gathered into high abundance in these stations.

Seen abundance differences between surface and bottom of the investigated area, abundance difference was bigger in spring, but not significant in autumn, which may be related to heterogeneity of the environment. Xiao (2002) found through bottom flow path of "artificial jellyfish" put in north-central Taiwan Strait in 1984 and seawater movement obtained by equidensity method of fractional steps that flow direction of surface layer sea water in Fujian sea area was subjected to significant seasonal variations, but South China Sea warm current near the bottom flowed northward all the year round. In spring, South China Sea warm current dominated southern waters of Fujian Strait, while Minzhe southward coastal current occupied coastal narrow surface waters from Chongwu to Pingtan Island, and joined underlying South China Sea warm current at waters near Nanri Island. In the case of the intersection of different river systems, seawater was with strong eddy mixture, and surface, underlying differences in marine ecological environment are significant, which exerted certain impact on phytoplankton growth and reproduction.

\section{Analysis of phytoplankton community structure}

Diversity index and uniformity of phytoplankton are shown in Table 1. As can be seen, the investigated area was with low phytoplankton diversity index in spring and autumn, diversity index range of variation in spring was between 1.76-2.85, with an average of 2.31, diversity index of coastal stations was higher than that of offshore stations; Diversity index in fall was generally relatively higher than that in spring, with average value at 2.58 and value range between 2.23-3.11. Only diversity indexes of offshore S6 and S9 station were $H^{\prime}>3.00$. In spring, continental runoff brought a wealth of nutrients to the coast. At a suitable temperature and under the condition of full complement of nutrients, individual phytoplankton species will thrive. For instance, Chaetoceros curvisetus abundance accounted for $33.07 \%$ of phytoplankton, as a result, phytoplankton diversity index of the season was low. Uniformity $\mathbf{J}$ was higher, variation range was between $0.59-0.77$ in spring, with average value at 0.69 . Variation range was between $0.59-0.83$ in autumn, with average value at 0.72 . Difference among stations was small. Species diversity index reflected degree of relation between phytoplankton species richness and inter-species number of cells, which was related to heterogeneity of environment. Uniformity which represented uniformity degree of species distribution within the community was one of characteristics whether community was mature and stable. By integrating above community characteristics index, it can conclude that the investigated area was of high environmental heterogeneity, relatively uniform inter-species proportion, lower species diversity index, phytoplankton community which has not yet reached a stable level.

Table 1. Structure of phytoplankton in waters around Nanri Island

\begin{tabular}{lllll}
\hline \multirow{2}{*}{ Station } & $\boldsymbol{J}$ & \multicolumn{3}{c}{$\boldsymbol{H}^{\prime}(\log 2)$} \\
\cline { 2 - 5 } & Spring & Autumn & Spring & Autumn \\
\hline 1 & 0.73 & 0.61 & 2.13 & 2.23 \\
2 & 0.75 & 0.59 & 2.75 & 2.41 \\
3 & 0.76 & 0.79 & 2.62 & 2.64 \\
4 & 0.61 & 0.69 & 1.76 & 2.34 \\
\hline
\end{tabular}




\begin{tabular}{lllll}
\hline 5 & 0.66 & 0.68 & 2.56 & 2.32 \\
6 & 0.69 & 0.82 & 2.29 & 3.09 \\
7 & 0.77 & 0.76 & 2.85 & 2.67 \\
8 & 0.64 & 0.73 & 1.86 & 2.58 \\
9 & 0.75 & 0.83 & 2.12 & 3.11 \\
10 & 0.60 & 0.81 & 2.25 & 2.91 \\
11 & 0.77 & 0.62 & 2.39 & 2.35 \\
12 & 0.59 & 0.65 & 2.12 & 2.35 \\
\hline
\end{tabular}

\section{Influence of temperature-salinit on diversity of phytoplankton}

In spring, the investigated area was still affected by Minzhe coastal current. Skeletonema costatum, which belongs to eurythermal and eurysalinity species, was extensively distributed at high abundance, making the abundance of phytoplankton at a high level in such season. Warm water species such as Lauderia borealis and Rhizosolenia stylilformis were intensively distributed in some station, which proved that offshore water of high temperature and high salinity began to affect the investigated area. In addition, influenced by Minzhe coastal current (Wan, 2013; Wang, 2011; Zhang and Kazerooni, 2016; Xiao, 2002), water system in the investigated area was relatively complex. Generally, it was mainly represented by mid-temperature high-salinity water $\left(18.63^{\circ} \mathrm{C}, 33.11 \mathrm{ppt}\right)$, with coexistence of eurythermal low-salinity species and eurythermal high-salinity species, which enriched the diversity of phytoplankton. In autumn, offshore high-temperature high-salinity water still dominated investigated area, making Chaetoceros distance and Chaetoceros lorenzianus gathered here at high abundance, which was consistent to features of high-temperature and high salinity water $\left(24.13^{\circ} \mathrm{C}, 30.19 \mathrm{ppt}\right)$ in the investigated area. Eurythermal species such as Asterionella joponica and Skeletonema costatumm become the major species in the investigated area; Warm water species such as Trichodesmium erythraeum, Chaetoceros lorenzianus, and Cyclotella caspia were sharply increased in quantity with increase of water temperature, which made a large contribution to the abundance of phytoplankton. In addition, due to Minzhe coastal current as well as southward drift of Minjiang River Tip (Wan, 2013; Xiao, 2002), the water salinity in investigated area decreased, so that Paralia sulcata began to extensive distributed and gained certain momentum. In such season, ecological type of phytoplankton was dominant by eurythermal species, and its species number accounted for a higher proportion that was $14 \%$ higher than that in spring, while the number of warm water species was relatively reduced.

\section{Correlation between phytoplankton abundance and environmental factors}

Investigation was conducted on waters in middle part of Taiwan Strait, and it can find that lower temperature low salinity high nutrient coaster water was in waning and waxing relation with high temperature high salinity low nutrient offshore water. .Such relation will lead to evolution of marine dynamic environment factors, and thus affected spatial-temporal change of chemical and biological factors, playing a vital role in controlling distribution and change of phytoplankton. Table 2 presents correlation between water salinity and environmental factors in spring in such investigation. It can been seen from Table 2 that salinity was in close negative correlation with nutrients, which indicated such area was influenced by intersection of low salinity high nutrients Minzhe coastal water and high salinity low nutrients offshore water. With mixing of two water systems, nutrients concentration was diluted as the increase of salinity. On the 
other hand, salinity was mostly correlated with nitrate, which indicated there was a low concentration of nitrate nitrogen in offshore water.

Table 2. Pearson rank coefficient of salinity and environmental factors (Pearson rank correlation coefficient, $N=12$ )

\begin{tabular}{ccccccccc}
\hline Season & Salinity & $\mathbf{C O D}$ & $\mathbf{D O}$ & $\mathbf{N O}_{\mathbf{3}}$ & $\mathbf{N O}_{\mathbf{2}}$ & $\mathbf{N H}_{\mathbf{4}}$ & $\mathbf{D I N}$ & $\mathbf{P O}_{\mathbf{4}}$ \\
\hline Spring & $\begin{array}{c}\text { Pearson } \\
\text { correlation } \\
\text { Autumn }\end{array}$ & -.359 & $.582^{*}$ & $-.776^{* *}$ & $-.697^{*}$ & -.114 & $-.757^{* *}$ & $-.670^{*}$ \\
$\begin{array}{c}\text { significance } \\
\text { (dual side) }\end{array}$ & .252 & .047 & .003 & .012 & .725 & .004 & .017 \\
$\begin{array}{c}\text { Pearson } \\
\text { correlation } \\
\text { significance } \\
\text { (dual side) }\end{array}$ & -.276 & -.089 & -.519 & $.789^{* *}$ & -.455 & -.490 & -.408 \\
\hline
\end{tabular}

Table 3 presents correlation analysis between spring phytoplankton density and environment factors, from which we can see that phytoplankton density was insignificantly related with $\mathrm{COD}, \mathrm{DO}$ and $\mathrm{NH}_{4}$, while in close negative relation with environmental factors such as salinity, $\mathrm{NO}_{3}, \mathrm{NO}_{2}$, DIN and $\mathrm{PO}_{4}$. This was due to water temperature recovery in spring, regeneration and collection of nutrients in winter, as well as large quantity of nutrients brought by continental runoff that made a mass propagation of phytoplankton, which thus directly led to an increased requirement for nutrients. In addition, from Table 2 it can be seen that nitrate nitrogen was the major composition of total inorganic nitrogen dissolved in investigated area. As phytoplankton consumed large quantity of nitrate nitrogen, $\mathrm{NH}_{4}$ was insignificantly related with phytoplankton density. Bronk et al. (1994) concluded kinetic process of nitrogen absorption by phytoplankton, which believed it was a energy consuming process for converting $\mathrm{NO}_{3}$ into $\mathrm{NH}_{4}$ via nitrate reductase, therefore $\mathrm{NH}_{4}$ was normally the first one to be utilized in the presence of different forms of nitrogen salts. However, according to research on marine area in waters around Nanri Island, it can find that it was probably because nitrate nitrogen was the major source in investigated area that nitrate nitrogen was the major nitrogen source absorbed for phytoplankton proliferation, which was basically consistent with results of research on Changjiang estuary by Hong et al. (1994). In natural marine area, concentration and composition change of different forms of inorganic nitrogen were affected by phytoplankton absorption effect as well as by external source imports and microbiological degradations. The reason why $\mathrm{NH}_{4}$ did not reduce with phytoplankton proliferation was probably because places where phytoplankton was in robust growth were normally associated with numerous actions of zooplankton, of which secretion and excretion can recover consumed $\mathrm{NH}_{4}$ (Shanggao, 1989). Therefore the change of different forms of nitrogen was generally the result of comprehensive action of different factors.

According to correlation analysis between salinity and nutrients in autumn (Table 2), it can find that nutrients except for nitrite were no longer significantly related with salinity, and the investigated area was dominantly affected by high temperature and high salinity $\left(24.14^{\circ} \mathrm{C}, 30.18 \mathrm{ppt}\right)$ offshore water, while slightly affected by low temperature low salinity Minzhe coastal current . In addition, as growth of phytoplankton entered into decline phase in this season, the requirement on nutrients was greatly reduced. Therefore phytoplankton density was no longer significant related to nutrients. 
Table 3. Pearson rank coefficient of phytoplankton density and environmental factors (Pearson rank correlation coefficient, $N=12$ )

\begin{tabular}{cccccccccc}
\hline Season & Density & Salinity & COD & DO & NO3 & NO2 & NH4 & DIN & PO4 \\
\hline Spring & $\begin{array}{c}\text { Pearson } \\
\text { correlation } \\
\text { Autumn }\end{array}$ & $.589^{*}$ & 0.056 & 0.538 & $-.596^{*}$ & $-.674^{*}$ & -0.242 & $-.612^{*}$ & $-.626^{*}$ \\
$\begin{array}{c}\text { significance } \\
\text { dual side) }\end{array}$ & 0.044 & 0.862 & 0.071 & 0.041 & 0.016 & 0.448 & 0.034 & 0.03 \\
$\begin{array}{c}\text { Pearson } \\
\text { correlation } \\
\text { significance } \\
\text { dual side })\end{array}$ & -0.064 & 0.351 & 0.05 & 0.364 & 0.33 & 0.226 & 0.333 & -0.249 \\
\hline
\end{tabular}

\section{Influence of human activities on phytoplankton communities}

Human activities are of increasing influence to marine environment, especially the eutrophication of water and overfishing have changed resource availability and marine food network structure, so that the whole marine eco-system has been impacted (Luo, 2011; Jin, 2012). The only report on change of phytoplankton communities in adjacent waters of Nanri Island recorded in history was an islands investigation material during 1990-1991 (Fujian Editorial Committee for Comprehensive Investigation of Sea Island Resources, 1994), in which the results showed that: concentration of labile phosphate in surface seawater in spring of 2011 was $0.008 \mathrm{mg} / \mathrm{L}$, and that in autumn was $0.025 \mathrm{mg} / \mathrm{L}$, which were 1.5 times and 1.1 times higher than that during 1990-1991; Concentration of inorganic nitrogen in spring of 2011 was $0.155 \mathrm{mg} / \mathrm{L}$, and that in autumn was $0.362 \mathrm{mg} / \mathrm{L}$, which were 2.15 times and 2.13 times higher than that during 1990-1991. It can be seen that concentration of nutrients in surface seawater have been increasing for the 20 years, which was probably due to expanded mariculture area, increased mariculture density, increased population, and increased discharge of domestic sewage, and caused nitrogen and phosphorus pollution in sea water (Luo, 2011; Jin, 2012). Increased concentration of nutrients was likely to cause proliferation of particular species, and thus infringed living space of other species, damaged structure of phytoplankton communities, and finally led to lower level of abundance and diversity index even with abundant species of phytoplankton. This was because the change of nutrients concentration was not only related to phytoplanton abundance, but also of significant influence to structure of phytoplankton communities (Vitousek et al., 1997; Micheli, 1999). Compared with 1990-1991, dominant species number in adjacent sea area of Nari island in spring was decreased from 8 to 4 , while that was decreased from 7 to 3 in autumn, moreover dominant species was evolved from both Diatom and Pyrrophyta to now Diatom (Egge, 1998; Shen, 2001; Tomera, 2014). This was because Pyrrophyta is of stronger adaptive capacity over Diatom under low concentration of nutrients, and in marine area where the sea water enjoyed balanced nutrients ratio and higher nutrients concentration, silicate can provide material basis for formation of silicious shell of Diatom, which is good for Diatom growth, therefore Diatom is dominant species of all phytoplanktons (Peng et al., 2006). According to research by Xu et al. (2010), the marine environment in Xinghua Bay had not been significantly changed under the influence of human activities over the past 20 years (Xu et al., 2010; Manson, 2016; Micheli, 1999). Zheng (2014) found in their research on zooplankton community in marine area near Nanri Island, at Xinghua Bay mouth, that although there were no significant changes over the past 20 years, zooplankton community structure had been subjected to large shocks due to decrease of 
nutrients concentration (Zheng, 2014), which was consistent with results of investigation on phytoplankton in this investigate, indicating that the marine eco-system of this area was suffering unstabilizing factors. Human activities including industrial and breeding pollution have changed the concentration and structure of nutrients in investigated area, which may affect structure of phytoplankton communities in certain degree.

\section{Conclusion}

Phytoplankton in waters around Nanri Island, which was dominant by eurythermal and eurysalinity species, was greatly affected by Minzhe coastal water as well as warm current of South China Sea. Phytoplankton was subjected to significant seasonal change of abundance and had different Biomass centers. The cell abundance of dominant species was large, with non-uniform inter-species distribution and lower diversity index. Salinity and nutrients concentration were two major factors affecting phytoplankton in investigated area, which were significantly related to phytoplankton abundance in spring. With increasing human activities over the past 20 years, nitrogen phosphorus concentration had been increased in certain degree, which created significant influence to structure of phytoplankton communities and made dominant species evolved from both Diatom and Pyrrophyta to now only Diatom. With establishment and operation of large nuclear power plants, reclamation projects and port engineering around Nanri Island, the eco-system and kinetic process of adjacent waters from Nanri Island had been more and more complex, therefore environment factors, which were of regulatory effect to composition, distribution and change of phytoplankton, should be further analyzed.

\section{REFERENCES}

[1] Borkman, D., Smayda, T. J. (2003): Long-term patterms of Narragansett Bay phytoplankton driven by decadal shifts in Phytoplankton habitat, 2nd Symposium on Harmful Marin Algae in the U.S., Woods Hole, MA(USA) 8-13.

[2] Bronk, D. A., Glibert, P. M., Ward, B. B. (1994): Nitrogen uptake, dissolved organic nitrogen release, and new production. - Science 265: 1843-1846.

[3] Cheng, Z. D. (1997): Planktonic diatom in south marine area of fujian and its seasonal variations. - Journal of Xiamen University (Nature Science) 18(4): 112-117.

[4] Committee of environmental experts, Ecological Society of Japan. (1987): Environmental and Biological Indicator (Sea Water). - China Environmental Science Press.

[5] Du, Q. H. (1996): Distribution of phytoplankton in waters around Nanri Island. - Journal of Oceanography in Taiwan Strait (15): 280-285.

[6] Egge, J. K. (1998): Are diatoms poor competitors at low phosphat e concentrations? Journal of Marine Systems 16:191-198.

[7] Fott, J., Pechar, L., Pražáková, M. (1980): Fish as a factor controlling water quality in ponds. - In: Barica, J., Mur, L. R. (Eds) Developments in Hydrobiology. Vol. 2. Springer Netherlands, pp. 255-261.

[8] Fujian Editorial Committee for Comprehensive Investigation of Sea Island Resources. (1994): Research Report of Comprehensive Investigation of Sea Island Resources in Fujian Province. - Beijing: Maritime Press 200-211.

[9] Fujian Marine Research Institute. (1998): Comprehensive Investigation Report of Mid-North Oceans in Taiwan Strait. - Science Press.

[10] Gao, Y. H. (2001): Research of marine microalgae classification and zoology and related bioactivators. - Journal of Xiamen University (Nature Science) 40(2): 566-573

[11] Hong, H. S. (1997): China collected works of oceanography-research of primary 
productivity of Taiwan Strait and its regulatory mechanism. - Maritime Press 1-204.

[12] Hong, J. C., Huang, X. Q., Jiang, X. S. et al. (1994): Analysis of environmental factors during red tide of skeletonema costatum in changjiang estuary-condition of nutrient salt. Oceanologia Et Limnologia Sinica 25(2): 179-243.

[13] Jin, D. X. (1982): Characteristics of diatoms in Taiwan strait. - Journal of Oceanography in Taiwan Strait 1(1): 80-86.

[14] Jin, Y. J. (2012): Evaluation of environmental change of abalone aquiculture area in Putian Nanri Island. - Chemical Engineering \& Equipment (8): 213-215.

[15] Li, D. L., Peng, W. X., Ge, S. B., Li, S. S., Mo, B., Ohkoshi, M. (2015): Groups characteristics of bioactivator extractives in three poplar woods. - Wood Research 60(5): 755-762.

[16] Lin, G. M., Yang, Q. L. (2007): Species diversity and the distribution of micro-phytoplankton in the Taiwan Strait. - Biodiversity Science 15(1): 31- 45.

[17] Liu, Z. F., Peng X. Y., Xu L., et al. (2000): Research of two voyages of Particulate Organic Carbons in Summer 1997 and Winter 1998 of Taiwan Strait. - Journal of Oceanography in Taiwan Strait 9(3): 95-101.

[18] Liu, Z. L. (2013): Evaluation on developing level of unban agglomeration derived from resources exploration. - Journal of Applied Sciences 13(21): 4702-4707.

[19] Luo, D. L. (2011): Diagnosis and evaluation of marine ecological environment in autumn of Fujian Nanri Island. - Chin J App Ecol 22(2): 495-502.

[20] Manson, G. K. (2016): Davidson-Arnott, RGD; Ollerhead, J., Attenuation of Wave Energy by Nearshore Sea Ice: Prince Edward Island, Canada. - Journal of Coastal Research 32(2): 253-263.

[21] Micheli, F. (1999): Eutrophication, fisheries, and consumer-resource dynamics in marine pelagic ecosystems. - Science 285: 1396-1399.

[22] Patsch, J., Radach, G. (1997): Long-tern simulation of the eutriphication of the north sea temporal development of nutrients, chlorophyll and primary in comparison. - Journal of Sea Research 38: 275-310.

[23] Peng, X., Ning, X. R., Sun J., et al.(2006): Responses of Phytoplankton Growth on Nutrient Enrichments in the Northern South China Sea. - Acta Ecologica Sinica 26(12): 3959-3968.

[24] Qi, Y. Z., Wang. Y. (2003): What the species of prorocentrum causing red tide of east china sea? - Chin J App Ecol 14(7): 1188-1190.

[25] Reynolds, C. S. (1984): The ecology of freshwater phytoplankton. - Cambridge University Press.

[26] Shanggao, J. W. H. (1989): Relationship between Nutrients, Salinity and Phytoplankton in Fujian Coastal Water. Tropical Ocean. - Journal of Tropical Oceanography 8(2): 55-64.

[27] Shen, Z. L. (2001): Historical changes in nutrient structure and its influences on phytoplankton composition in Jiaozhou Bay. - Estuarine, Coastal and Shelf Science 52: 211-224.

[28] Tomera, M. (2014): Dynamic positioning system for a ship on harbour manoeuvringwith different observers. Experimental results. - Polish Maritime Research 21(3): 13-24.

[29] Vitousek, P. M., Mooney, H. A., Lubchenco, J., Melillo, J. M. (1997): Human domination of earth's ecosystem. - Science 227 (5325): 494-499.

[30] Wan, X. F. (2013): Seasonal variation of the hydrodynamic environmentin the western Taiwan Strait. - Journal of Oceanography in Taiwan Strait (21): 156-163.

[31] Wang, Y. (2011): Structure of phytoplankton community during the fading period of zhemin coastal water in Taiwan Strait. - Marine Science Bulletin (30): 221-225.

[32] Wong, Y. S. Tam, N. F. Y. (Eds) (1995): Asia-Pacific Symposium on Mangrove Ecosystems. - Kluwer Academic Publishers.

[33] Xiao, H. (2002): Research review of hydrographic characteristics in Taiwan Strait. - 
Journal of Oceanography in Taiwan Strait (21): 126-138.

[34] Xie, W. L., Chen, C. P., Gao, Y. H. (2007): Structure of diatom community in sea water from mid-north of Taiwan strait to Nanji islands in winter of 2005. - Journal of Oceanography in Taiwan Strait 26(3): 370-379.

[35] Xu, X. Q., Zeng, J. N., Shou L., Le, F. F. (2010): Horizontal distribution and seasonal variation of zooplankton community in Xinghua Bay. - Acta Ecologica Sinica 30(3): 734-744.

[36] Yang, Q. L. (1995): Species composition and distribution of planktonic diatoms in west side of Taiwan Strait. - Acta Oceanologica Sinica 17(2): 99-107.

[37] Zhang, F. Y. (2009): Comparision of change histories of phytoplankton in Changjiang estuary and neighboring sea areas and research of its environment factors. - Shanghai: East China Normal University.

[38] Zhang, J., Kazerooni, H. (2016): Consideration on the building of urban landscape sports culture. - Journal of Mechanical Enigeering Research and Developments 39(1): 83-87.

[39] Zheng, H. D. (2014): Abundance and distribution of aooplankton in waters around Nanri Island of FujianNanri Island. - Journal of Fujian Fisheries (2): 185-190. 